\title{
The Freedom of Religion in the Post-Soviet Georgia
}

\author{
Manana Darchashvili * \\ Tina Tskhovrebadze **
}

\author{
ARTICLE INFO \\ Article history: \\ Accepted: October 302020. \\ Approved: December 152020.

\section{Keywords:} \\ Georgia, Politics, Religion, \\ Freedom, International Or- \\ ganizations, the Georgian \\ Government, Religious \\ Challenges.
}

\section{A B S T R A C T}

After declaring the independence of the Georgian state at the end of the 20th century Georgia faced different kinds of challenges in internal politics and one of the most important issues among them was a peaceful coexistence of multi-ethnical and multi-religious groups in the new realities. Any governments of Georgia have always taken into consideration the issue.

Depending on the actuality of the theme, we define the main aim of the paper, which is studying the quality of the freedom of religion in PostSoviet Georgia. The work analysis the content of the research-based documents on freedom of beliefs and religions, prepared by different international organizations, and how the Georgian government reacts and answers to the dilemmas of freedom of religion. The empirical data such are - scientific works, research papers, official documents written by the state institutions discussed with the historicism method.

The paper suggests different angles of view over the religious freedom reality in Georgia - how effective are tools and steps made by the Georgian government for solving the controversy or similar flows in society. What kinds of arrangements do the government creates for implementing recommendations worked out by the international organizations and guaranteeing basement religious freedom, respect for them, and tolerance.

Modern Georgian policy on religion is oriented on peaceful examples shown by various counties political experience and nearest past, it relies on new trends in global politics and is looking for ways for creating a comprehensive environment for religious freedom and expression, at least all those measures serve and are meaningful pillars for creating democratic prosperity in Georgia.

(C) 2020 Published by the Institute for Development Studies, Sulkhan-Saba Orbeliani University.

\footnotetext{
* Doctor of History, Georgian Technical University, Tbilisi, Georgia.

** Ph.D. Student, Ivane Javakhishvili Tbilisi State University, Tbilisi, Georgia.
} 


\section{JOURNAL OF DEVELOPMENT STUDIES}

\section{Introduction}

The issue of freedom of religion is essential and perceived as an inviolable dignity of the individual and, therefore, is the subject of urgent debate, especially after declaring the Georgian statehood independence. Following the main principles of freedom of religion is a necessary condition for the establishment of democracy in such a multi-religious country as it is Georgia. At the same time, Georgia is a zone of contact between Western and Eastern cultures, which is why the issue has repeatedly been discussed and droves the attention of the researchers on a local and an international level.

In the post-soviet period, it is possible to express thoughts and share religious values. Studying the issue is more important and actual due to building a politically stable country, based on the results of the research paper suggests recommendations for the policy of religion in Georgia.

The work represents the reality in the country, more concretely how the religious diversity serves concrete political interests in the state of Georgia and also the main official policy, which is oriented on regulation the situation and following the democratic values in shaping the peaceful environment for any type of religion in the country. The measures implemented by the government of Georgia tend to enhance the freedom of religion and expression of thoughts in the whole territory of the state. Findings of the research regarding the effective solutions would enrich the Georgian government policy for stabilization and democratic development processes in the country.

It must be mentioned that there are different kinds of literature on the religious diversity of Georgia published within decades. Most of the works describe how religion and religious institutions form the society, what is the dynamic among the local various religious groups, vast of the papers make an accent on peaceful coexistence in the religiously diverse country.

\section{The Cases of the Religious Confrontations in the Georgian Reality}

There had been facts of the conflicts between different religious groups of the country in the post-soviet period in Georgia. The most well-known cases through the last years occurred in the villages inhabited by both orthodox Christians and Muslim citizens of Georgia. For example in Nigvziani (common traditional prayer was avoided), in Tsintskaro (removing the cross from the grave gates), Samtatskaro (Christians canceling the Muslim prayers), Mokhesa (dispute over the building), Chela (The fact of unauthorized construction of the minaret).

While monitoring the process over the mentioned cases a few tendencies that merits attention as such the comments made by the politicians regarding the events connected to the religion or religious institutions. The public actors mostly do not follow the religious neutrality principle and they tend to make biased comments according to their belief system or mainstream religious conjuncture. At the same time, there were some occasions when the political parties used the factor of religion as an option to reserve the vote in the elections. Some politicians avoided expressing the positions based on the principles of equality, tolerance, and secularism.

In the last 30 years, there had been some complaints about insulting orthodox Christianity (which is thought to be a traditional religion in Georgia and around 83\% of the citizens of Georgia follow orthodox Christianity). For instance, some Christian symbols were expressed in an inappropriate manner, which aroused negative feelings in many people so, the demand for regulation of the situation in some forms (at least on the legal basis) started to grow from the society and surely 


\section{JOURNAL OF DEVELOPMENT STUDIES}

some of the governments supported and idea.

Another fact the paper pays attention to is the summaries of religious or non-governmental organizations that are concerned about the tendency of the Georgian Orthodox Church being prioritized in the process of returning the buildings confiscated by the Soviet State. Some representatives of the Georgian church do not accept the work of the NGO-s that focus on the issue of human rights and especially on the rights of minorities.

Although there are examples of positive cooperation between churches and NGOs. It is interesting that cases like that consist of themes such as Euro-integration. So, it is evident - the blames of the church being antiwestern oriented is not based on the truth and shows the progressive development of the official Georgian church in striving to the western culture (Monesashvili, 2017). The pro-western positions are evident in the epistles of the head of the Georgian Church Catholicos-Patriarch of all Georgia Ilia the Second (Darchashvili, 2015). In any kind of confrontation. Ilia II always tries to support peace among the people belonging to different religions.

\section{The Georgian Government on the Free- dom of Religion and Approaches to the Is- sue of Freedom of Religion}

Georgia has made her choice in favor of Western-European values after redeclaring her independence. In 2005 Georgia ratified the European Framework Convention for the Protection of National Minorities according to which Georgia has worked on the civil consent and integration state strategy aiming to gain a common understanding and ensure equality (Ordinance of the Government of Georgia \#1740, 2015).

The strategy shares the main commitments made in the Association Agreement between Georgia and the Council of Europe in 1999 also Georgia made commitments to the aims of the agreement of Deep and Comprehensive Free Trade Areas (DCFTA) in 2014, follows the international treaties. All those agreements focus on democratic reforms. As we know, cultural diversity, religion, protection of freedom of belief and integration are the main pillars of democracy. To implement the main goals Georgia adopted the action plans for decades. It is essential for the country that is strongly oriented to be a full member of European structures to protect human rights and ensure respect of fundamental values of freedom through collaboration according to the standards and recommendations are given by the European Union (The State Agency for Religious Issues in Georgia, 2014).

In 2014 the Georgian state took initiation of founding the State Agency for Religious Issues in Georgia. The organization is subordinated to the Prime Minister of Georgia. The other positive and meaningful aspect of creating the institution was the involvement of qualified experts and scholars in the process. The agency has a specialized structure that suggests policy on religion. It is based on national experiences and modern challenges of the civilized world. The State Agency for Religious Issues in Georgia to develop recommendations in the sphere of religion in accordance with the modern challenges and field of its competencies built on scientific knowledge of historical experiences and general values of mankind (The Constitution of Georgia, 2017). The agency owns the prerogative to distribute state compensation to religious organizations (Roman Catholic Church, Muslim and Jewish Communities, Armenian Apostolic Church) registered as legal entities under public law. The state compensates them for "material and moral damages during the Soviet period" (The USA Embassy Annual Report, 2016). They get concrete sum annually since 2014 and the Government of Georgia defines the amount of money per 


\section{JOURNAL OF DEVELOPMENT STUDIES}

year (Noniashvili, 2020). Since 2014 The Recommendation Commission of the Property and Financial Commission of the State Agency for Religious Issues discussed the cases of delegation of the religious buildings to the religious unions and the issue of permitting construction of new buildings, but herby it must mention that decisions of the commission are recommendations as long as the commission does not own the right of disposal of the property. It is remarkable to mention statements made by the agency on the facts proving discrimination of the freedom of religion in the occupied territories of Georgia.

The NGO focusing on religious issues is the Diversity and Tolerance Institute that was founded in 2013. Enhancing and supporting the freedom of religion, diverse culture, civil integration, dialog among the cultures, building a secular state are the main aims of the organization. The projects implemented by the NGO (financed by international society) focus on the major themes of the Diversity and Tolerance Institute. Both of the institutions - the State Agency for Religious Issues in Georgia and the Diversity and Tolerance Institute have made meaningful reports on the situation in the country and the documents will help to improve the situation in favor of the democratic developments in Georgia (The Diversity and Tolerance Institute, 2020).

\section{Georgia - In the Context of Assessing the Religious Freedom of the Civilized World}

In the modern world security, peace, solidarity, cooperation, mutual respect, a commonwealth belong to the main interests of the states. In the XXI century, the mainstream of the international society is to find solutions to the challenges that face the global world. The ways of solutions base on democratic, fair principles which help to grow the friendship among the countries and make it possible to live in a peaceful world altogether.
It is important to mention that interreligious visions of living put the accent on the necessity of developing new global ethics, which has a meaningful role in creating a comfortable environment for cultural and religious relationships (Tolerance and Diversity Institute, 2018). As for Georgia in a global context, she aims to create the laws that are fair to all kind of religious groups and unions that exists in the country.

The government of Georgia on the one hand focuses on the peaceful environment and spreading democratic values through the country and keeps in mind the attitude of the partner states of Georgia on the other hand. For instance, Georgia values and follows the recommendations mentioned in the reports of the US Department of State on the freedom of religion in Georgia (Tolerance and Diversity Institute).

The First Ministerial devoted to Advance Religious Freedom took its place in Washington D.C. on July 24-26 in 2018. The Minister of Foreign Affairs of Georgia had a speech on the Ministerial and he mentioned the situation in Georgia. He spoke about the Georgian history that is famous for its tolerance and multicultural characteristics. The cultural diversity and religious pluralism are the main features of the Georgian nation - mentions David Zalkaliani. He also stated - supporting and guarantying religious freedom in Georgia is the main priority of the Georgian government and herby he mentioned the meaningful policies that official structures of Georgia carried out, the minister recalled the case of contributing constructions to the religious confessions and unions. David Zalkaniani paid attention to the positive involvement of the religious institutions in the process of EuroAtlantic integration of Georgia.

The Minister of Foreign Affairs of Georgia spoke about the current circumstance in the occupied regions of Georgia - concretely he discussed the facts of damaging and destroying historical churches on a purpose, violating 


\section{JOURNAL OF DEVELOPMENT STUDIES}

the rights of believers, and as Mr. Zalkaniani mentions the occupier regime of the Russian state tries to vanish the historical Georgian trace and artifacts from the occupied territories of Georgia. The Minister addressed the international community for the adequate and proper action to the facts of offending the international laws and the fundamental Human Rights by the Russian Federation.

David Zalkaniani in a name of the Georgian people and the Georgian Government proved the readiness for dialogue of civilization and build bridges among the diverse cultural and religious groups and deepening the trust that was the successful work of the Georgian state throughout the centuries.

The XXI century shows that interaction among diverse individuals and groups is as essential and central paradigm as in between similar ones. Nowadays, it is rare to see the hegemonic society in which the members belong to the same religious group. Having that said Georgia realizes the interreligious groups' dialogues role in a peacebuilding process.

\section{The Presidents of Georgia about the Freedom of Religion}

Freedom of belief was strongly established in Georgia for centuries. The political memory of the country kept evidence of respecting religious differences in the country. The rulers of the Georgian kingdom realized religious verities, caused by the geopolitical position and were willing to build the country with the peaceful coexistence of the multi-religious society.

In the 20th century, when Georgia founded the first nation-state the Democratic Republic of Georgia religious groups had the freedom of belief and expression. Those days did not last for long and after the Soviet occupation, Georgia was forced to have only one religion - The Soviet Ideology. In the Soviet Republics, no one could freely express their religious feelings, views, and beliefs. As soon as Georgia redeclared her freedom and independence and got elected the parliament and the president of Georgia, the religious institutions started to reappear in the cultural, social, political life of the country. The Georgian Government puts an effort to improve the national legislation and fulfill the commitments made by signing the documents with the international structures. The empirical data collected in the process of research show the tendency through the different presidents and administrations. The presidents of the country and decision-makers were and are always oriented to keep up with the recommendations and western values. As long as the format of the paper does not allow to deliver an analysis of all speeches made by the presidents of Georgia in various cases and periods, the research team pays attention to the first president's Zviad Gamsakhurdia's and current president's Salome Zurabishvili's speeches. Hereby must be mentioned that also the second, third, and fourth presidents of Georgia always made statements oriented on tolerance.

The first president of the independent state of Georgia Zviad Gamsakhurdia mentioned it right about the negative influences of the totalitarian and dictatorial regime of the Soviet Union. According to his words, not only social, political, and economic problems destroyed humanity but most of all, the absence of cultural and religious values did. Forgetting the spiritual ideals, losing human morality and vanishing beliefs threaten the wellbeing of the human race. The way out of the situation for him was radical reforms in the structures of protecting cultural heritage, restoring the statehood and independence by restoring the faith and morality as it was done in the past times in Georgia. Gamsakhurdia mentioned that the Orthodox Christian Church would not participate in the political processes directly and dividing the spiritual and political life of the nation did not mean 


\section{JOURNAL OF DEVELOPMENT STUDIES}

that the church and state shut the doors to each other. The first president of Georgia had the right vision of the role of the Orthodox Church in the political history of the state. Hereby he would always mention that the recognition of the power of the Georgian Church did not mean to violate the rights of the other religious unions, also he supported protecting the civic rights of those who associated themselves with atheism. Zviad Gamsakhurdia in his speech says: 'The state will support freedom of dignity and each individual will get an opportunity to be a member of the religious group or union which he/she recognize for her/himself. The rights of the civilians won't be limited based on what kind of religious group they belong to. Georgian state will be faithful again to the traditions of the religious tolerance' (Gamsakhurdia, 1991).

As for the acting president of Georgia Salome Zurabishvili she even mentioned in the pre-election period of her campaign that Georgia was a tolerant state, she respected all religions and she was going to be a tolerant president of Georgia (Zurabishvili, 2018).

The fourth president of Georgia mentioned several times that respecting the freedom of religious belief $s$ is meaningful, as long as "religion is strongly connected to the Georgian spirit and culture, therefore Georgian religion and culture are deeply linked to one another" (The First Channel, 2020).

In the interview with the TBN Jerusalem office, Salome Zurabishvili mentioned that the Jews arrived in Georgia even before the Christianity era in Georgia, and they were warmly met and greeted. They always felt at home and that's why Georgia became their second homeland for the Jews. This is an example of tolerance to the world (The First Channel, 2020).

It is evident all official persons, heads of states always support religious and cultural diversity in Georgia and are tolerating any religious groups in the country. Diversity is a heritage that is accepted and appreciated by the Georgian state. A good example of the support expressed by Eduard Shevardnadze the second president of Georgia (Shevardnadze, 2003). In his statement made as an answer to the provocative incident in the country Shevardnadze declares that he is against any kind of religious extremism awaking in the state, Georgia took responsibility to follow the recommendations and main principles of the signed documents with the Council of Europe, The United Nations and other international organizations (Shevardnadze, 2003).

\section{Conclusion}

Based on the analysis of the data two main aspects are worth to mentions: the freedom of religion is the actual issue in the Georgian state, despite the facts showing some misunderstandings and conflict situations between different religious groups the administrative representatives of the state administration take adequate steps towards the peaceful regulation of the problems, building trust and mutual understanding for protecting the religious minorities in the country. The second finding is that the occupied territories of Georgia with the various challenges in the regions because of the Russian occupation face different kinds of problems and one of them is freedom of belief, protecting religious places and churches which are the visible heritage of the history in the regions.

Keeping those tendencies in mind, the recommendations are more active policy to raise the awareness of ordinary people in Georgia with increasing educational resources that are easily accessible to any groups despite their place of living, age, and gender, ethnic or religious belonging. To follow the recommendations given by the US Department of State, the Council of Europe, NGOs working on the issue of human rights, 


\section{JOURNAL OF DEVELOPMENT STUDIES}

and others. Public discussions and debates to stimulate gaining mutual understanding are also great tools to bring diverse minds closer.

\section{References}

Darchashvili, M. (2015). Globalization, Development, and Perspectives, The Religious Aspects in Georgia in the End of the $20^{\text {th }}$ Century; Kyiv.

Gamsakhurdia, Z. 1991. The Inauguration Speech. [Online] Available: https://zviadgamsakhurdia.word-

press.com $/ 2012 / 10 / 25 / \%$ E1\%83\%A1\%E1\% (January 10, 2020)

Monesashvili, S. (2017). The Georgian Institute of Politics. The Georgian Orthodox Church as the Civil Actor: Challenges and perspectives, [Online] Available: http://gip.ge/wp-content/uploads/2017/05/\%E1\%83\%9E\%E1\%83\%9D\%E1 \%83\%9A\%E1\%83\%98\%E1\%83\%A2\%E1\%83\%9 8 (December 2017)

Noniashvili, G. (2020). The Tolerance and Diversity Institute, Restitution Center in Georgia http://tdi.ge/sites/default/files/restituciis politika sakartveloshi.pdf [Online] Available: (N.D. 2020)

Shevardnadze, E. 2003. Shevardnadze states for Avoiding violence on a religious basis. [Online] Available: https://civil.ge/ka/archives/129134 (March 5, 2020)

The International Reports on Freedom of Religion, Georgia 2016. [Online] Available: https://ge.usembassy.gov/ka/our-relationship-ka/official-reports-ka/int-religious-reports-ka/ (September 20, 2020)

The Constitution of Georgia, the Constitutional La, Tbilisi 2017, [Online] Available: https://matsne.gov.ge/ka/document/view/3811818 (December 25, 2019)

The Ordinance of the Government of Georgia \#1740, Tbilisi 2015. [Online] Available: http://gov.ge/files/410 50997650312 N174 0.pdf (http://tdi.ge/ge/mimdinare-proektebi (January 20, 2020).

The Tolerance and Diversity Institute, 2020 [Online] Available: http://tdi.ge/ge/mimdinare-proektebi (September 12, 2020)
The State Agency for Religious Issues in Georgia, The Annual Report June-December 2014, Tbilisi 2014. [Online] Available: https://religion.gov.ge/wliuri-angarisebi/religiis-sakitxtasaxelmwifo-saagentos-angarisi-2014-wlisivnisi-dekemberi (April 5, 2015)

The US Department of State Report on Georgia, The USA 2016. [Online] Available:

https://www.tdi.ge/ge/news/456-ashsh-religiistavisuplebis-angarishi-sakartvelos-shesaxeb (January 9, 2020)

Zurabishvili, S. 2018. I am not a Catholic, I am the Martmadiani. [Online] Available: http://liberali.ge/news/view/39839/audio-salomezurabishvili-ara-var-katolike-var (February 1 , 2020) 